\title{
Современные особенности женских ритуалов
}

\author{
Маре Кыйва \\ Отделение фольклористики, Эстонский литературный музей, \\ Эстония \\ mare@folklore.ee
}

Аннотация: В статье описывается создание современных женских ритуалов как элемента эстонских (этнических) неорелигиозных культурных феноменов. Несмотря на то, что ритуалы имеют несколько различные корни и формы, они представляют собой синкретический сплав и дальнейшее развитие эстонской календарной традиции, а в наиболее распространенных женских праздниках и связанных с ними ритуалах прослеживаются черты философии и практик ньюәйдж и значительное воздействие дискурсов эстонской традиционной религии (эст. maausk).

Посредством микросоциального сценария женского ритуала я описываю ритуалы, реконструированные и воссозданные с опорой на фольклорные тексты и знания и личную креативность. На пространственно-временные требования, дресс-код и символику ритуалов, а также на структуру реконструированной обрядности оказали влияние требования современного общества. Как для проводников, так и для участников важны личный опыт, происходящая в процессе проведения ритуала социализация участников с т.н. женской силой; создание новых ритуалов тесно связано с процессом конструирования своего «я» и идентичности.

Ключевые слова: неорелигиозные движения Эстонии, этнические верования, календарные праздники, женские ритуалы, воссоздание ритуалов, обряд приготовления каши, структура ритуала, неоязычество 


\section{Введение}

Существуют десятки определений понятия «ритуал», ограничусь двумя основными и взаимодополняющими, используя в качестве структурной модели теорию эффрективности ритуалов. По определению социального антрополога Стэнли Дж. Тамбия, ритуал представляет собой упорядоченную структуру слов и действий, различными способами выражающих смысл и договоренности. Ритуалы характеризует различная степень формальности (конвенциональности), стереотипности (неизменности), интеграции (слияния) и избыточности (повторов) (Tambiah 1979). Относительно схожей является трактовка Пьера Бурдьё. Он рассматривает ритуал как особую социальную структуру, включающую в себя время и ритуальное место, объекты и взаимодействие, тело и язык, а также как структуру связанную с социальными нормами и ценностями (Bourdieu 1994). Интересный аспект затронул антрополог Уильям Сакс, исследования которого посвящены вопросу эфрфективности ритуалов. Он характеризует ритуал как постпросветительский термин, отражающий трудности, которые возникают у нас при классификации определенных иррациональных совокупностей действий. По мнению У. Сакса, в общественном сознании ритуалы считаются не иррациональными, а скорее неэффрективными, что проявляется, например, в прописных истинах: «Мы знаем, что шаманские ритуалы лечат, юридические - ратифицируют, политические ритуалы объединяют, а религиозные ритуалы освящают» (Sax и др. 2010: 4 и далее).

Я исхожу из гипотезы, что женские ритуалы представляют собой «саморелигию, поддерживаемую личной экзегезой и выбором индивида» (York 2001), которой сопутствует возведение саморелигии в ранг ритуала (сакрального, профанического или секулярного), и выбрала для исследования двух входящих в различные культурные группы выдающихся деятелей, занимающихся созданием женских ритуалов: проводника творческих ритуалов, целительницу Туле Леэ (в миру - Мерле Мёльдер), и участника фольклорного движения, преподавательницу Эне Лукка. На их примере я рассмотрю, каким образом личностное развитие привело к созданию женского ритуала, а развитие идеи - к популяризации результатов и принятию ответствен- 
ности. На мой взгляд, возникновению и укоренению ритуалов может способствовать именно их эффрективность. Поскольку рассматриваемые ритуалы связаны с важными датами ритуального года, рассмотрим подробнее два женских ритуала, их сходства и различия, а также попутно - механизмы создания сакрального пространства.

Помимо интервью, я использовала различные информационные каналы, так как рефлексивная интернет-среда делает более заметным взаимодействие лиц и идей, а также когнитивную систему развития личности (см. Whitehouse \& McCauley 2005).

\section{Создание ритуалов в ближайшей перспективе}

Укоренение ритуалов как комплексный и всеобъемлющий процесс выводит на первый план различные ценностные пространства и мировоззрения. Подобно иным явлениям современной культуры, при семантическом толковании происходящего, наряду с деятельностью и текстами, представляет важность фиксация мировоззрения и действительности, сконструированных социальными группами и в особенности их лидерами, непосредственно на месте событий. Плюралистические современные ритуалы несут в себе общее инвариантное послание и, как правило, открыты для всех - без исключения по половому признаку (Паневритмия Петра Дынова) или осознанно предполагают равное представительство обоих полов (ритуалы в честь дней равноденствия/солнцестояния Вигала Сасся). ${ }^{1}$ Укоренение ритуалов, предназначенных исключительно для женщин, весьма удивляет, по всей видимости, занимая определенную социальную нишу, и нуждается в рассмотрении во всем своем разнообразии и вариативности. Эстонские женские ритуалы связаны с различными объединениями и лицами: членами этнического (языческого) религиозного движения, креативными интеллектуалами, целителями, инструкторами по культурным и духовным практикам. Также очевидно, что создание новых ритуалов опирается на предшествующую традицию или связано с аналогичными новыми движениями. Что взяли за основу в Эстонии? 
Предшественниками женских праздников были приходившиеся на осенне-зимний и весенне-зимний период традиционные праздники, во время которых запрещалось выполнять женскую работу (ср. Kõiva \& Särg \& Vesik 2004). Наряду с праздниками, во время которых запрещалось работать, внимания заслуживает обычай употреблять на День свечей/Сретение (2.02) и/или Благовещение (25.03) красный напиток, символически даривший женщинам красоту и здоровье. В XIX веке женщины имели право сообща отмечать праздник в трактире, позднее обычай модифицировался. В XX веке на городских рабочих местах предлагались красный напиток, пирожные или корж, некоторые отмечали Благовещение и в семейном кругу, что является удачным примером адаптации на фроне повсеместного исчезновения традиционных праздников. Возможно, свою роль сыграло сопротивление официально насаждавшемуся с 1960-х годов Международному женскому дню (Kõiva 2013)? Это способствовало в 1990-х годах тому, что отдельные группы и компании стали отмечать Благовещение как «праздник женской силы», во время которого принято приветствовать солнце и вкушать красный напиток (Kõiva 1995).

Известно, что на православных территориях Северо- и ЮгоВосточной Эстонии существовали парные праздники, т.е. женские и мужские праздники, отмечавшиеся примерно в одно время. На Юрьев день или незадолго до него женатые мужчины справляли мужской праздник, сетуские праздники, посвященные богу Пеко, ${ }^{2}$ проводились весной и осенью (Hagu 1975) - оба праздника перестали отмечать, по всей видимости, в начале прошлого века. В Северо-Восточной Эстонии традиция отмечать красочный женский праздник и имитировать приготовление сливочного масла на Юрьев день угасла в начале прошлого столетия. Единственной сохранившейся традицией является празднование в Юго-Восточной Эстонии, в местах проживания сету, женского праздника (эст. baabapraasnik) на Власьев день, Страстную неделю, Троицу или иную знаменательную дату (ср. Tampere 1960: 25). Женщины получали право участвовать в нем по истечении первого года замужества, и празднование отличалось свободой от условностей: пили алкоголь, веселились и танцевали. Женские праздники служили своеобразным социальным клапаном, а также средством объединения недавно вышедших замуж женщин с общиной (cp. Loorits 1940). В Юго- 
Восточной Эстонии традиция женских праздников сохранилась и после Второй мировой войны, однако, к сожалению, празднование знаменательных дат послевоенного периода изучено мало. Опубликованные в СМИ истории свидетельствуют о том, что работники культуры и сетуские песенные ансамбли поддерживают их модернизацию и празднование.

Подробнее о сетуском женском празднике рассказала Мерле Томбак. «Баба-праздник - это женский праздник. Они собираются и выбирают из своего числа хозяйку праздника, которая должна быть одета в национальный костюм. На женском празднике едят и пьют, шутят и, разумеется, танцуют и поют. Там очень весело», - объяснила она (Pulk 2008).

Наряду с традиционными формами ритуалов, в 1980-х годах возникло большое количество спонтанных неоязыческих (maausk), а также целительских и эзотерических ритуалов (подробнее см. Kõiva 1995, 2017). Своеобразный тип женских праздников, обряды приготовления каши ${ }^{3}$, центре которых стоит приготовление каши под народные песни ${ }^{4}$, зародился на Сааремаа, в деревне Трийги, в женском ритуальном комплексе, построенном рядом со святилищем Вигала Сасся (подробнее см. Kõiva 2018). После первого опыта ритуал решили повторить, непосредственно в начале XXI века он проводился во многих местах. В его фрормирование внесли свой вклад исполнительница сетуских песен Ыйе Сарв, поэтесса Каукси Юлле и мн. др. Этнографр и скульптор Эло Лийв (р. 1971), впоследствии председатель Саареской палаты народных верований, сформулировала потребность в подобном мероприятии следующим образом:

В мировой литературе описано очень много мужских ритуалов, а о женских знают мало. Это потому, что в свое время этнографами являлись мужчины, а их на эти ритуалы просто не пускали. Каждый род хранит секреты женских ритуалов гораздо тщательнее, чем мужских, ведь они связаны с домом, процветанием и детьми. И поскольку чужакам их не демонстрировали, то возникло мнение, что женских ритуалов и не существует (Linnard 2002).

На своем сайте она приводит еще более точное описание сути ритуалов:

Смысл заключался в том, что поскольку женщине дана сила рожать, создавать новую жизнь, она также обладает силой 
влиять на процветание всего мира, общаться на эту тему с богами. Различных матерей (мать земли, мать воды, мать огня и т.д.) приглашали варить вместе кашу и пели им благодарственные песни, чтобы всё в мире оставалось, как есть, иносказательно просили также хранить это (Liiv 2002, 2009; Linnard 2002; Salong 2010; Hallo Kosmos 2013).

\section{Ритуалы, созданные целительницей}

Мерле Мёльдер (р. 1972) является признанной целительницей. Изучая медицину в Тартуском университете в течение трех лет, она начала параллельно заниматься целительством. Признанная представительница альтернативной медицины Южной Эстонии начала проводить лечебные ритуалы уже в 1992 году на хуторе Леэсоя в Западной Эстонии. В честь родного дома Мерле использует псевдоним «колдунья из Леэсоя», под которым она известна и среди местных жителей. Звание колдуна является одной из немногих сохранившихся традиционных страт, к которой относят целителей и лиц с паранормальными способностями. С 2004 года она использует при проведении ритуалов и занятии альтернативной медициной имя Туле Леә, которое считает своим настоящим именем.

В 2004 году после одного ритуала я почувствовала, что имя Мерле Мёльдер для меня в прошлом, и совершенно осознанно, а затем и официально я взяла себе новое имя Туле Леэ, это мое имя, я выбрала его сама и довольна им.

В центре практик Туле Леэ находится целостность человека. Наряду с лечением, она начала создавать различные ритуалы, некоторые из них связаны с оздоровительными практиками, другие - с календарным циклом, включая женские обряды в специальной священной роще. В ходе ритуалов с этническим колоритом участники освобождаются от имеющихся познаний и тревог, городского стиля жизни, испытывают единение с природой и друг с другом и живут в естественных условиях. Изначально ее вдохновили вышеупомянутые обряды приготовления каши.

Не помню, в каком году, наверное, в 2003, когда я начала ходить к Эло варить кашу, до лета 2005 года. Затем осенью 2005 года 
я впервые провела женский обряд приготовления каши на женском месте в Леэсоя, нас было шестеро. И повязали в Священной роще первые ленты для матерей. Причин, по которым я начала проводить [ритуалы], было две: 1) Чтобы в местной общине был свой обряд приготовления каши для женщин, 2) заговоры были на эстонском языке. У Эло были песни на языке сету, и мне сложно было их понимать, язык чужой, и приготовление каши - немного тоже. Затем Эло еще сказала, что я не могу руководить ритуалом, поскольку у меня нет дочери, только два сына. В декабре 2006 года родилась маленькая Леэ, которая принимает участие во всех моих обрядах приготовления каши и в праздновании дней равноденствия и солнцестояния (Thule Lee 2013).

В ее ритуалах большое значение отводится самостоятельно созданным заговорам, совместному приготовлению каши, хождению по кругу, живому огню, возложенным к костру или брошенным в огонь растениям. Воззрения Туле Леэ сочетают в себе полученные академические знания, черты эстонской традиционной религии, эмпирический опыт, практики восточного происхождения, глубинную экологию и многие другие (переданные) знания. Поскольку она три года проучилась на медицинском фракультете по специальности "лечебное дело» и не отвергла полученные знания на пути к своим корням, это влияет на ее жизненные решения. Она перечисляет важные умения следующим образом:

[--] Всю свою сознательную жизнь я развиваю свои способности. Я занимаюсь ритуалами, заговорами, чтением знаков и целительством. Смотрю на мир сквозь призму познания и интуиции. Каждый знак является для меня предзнаменованием - если всё время жить в мире ритуалов и предзнаменований, можно обрести гармонию с собой и миром. Я живу в лесу, вдали от людей. В тишине, темноте и естественной свободе (Mölder 2010, Овальная студия, личный архив).

Топология обрядов Мерле является сплавом натурального хозяйства, архаического и современного, ее характеризует создание символического, воображаемого пространства. Обряды проводятся в заложенной в 1996 году священной роще, специальном месте проведения лечебных ритуалов и ритуалов в честь дней солнцестояния и равноденствия. Создание священной рощи на новом, так называемом «пустом месте», которое прежде не использовалось для таких целей, было новаторством. Как 
правило, святилище создается на месте, которое ранее считалось святым, или там, где священными считались, по крайней мере, элементы ландшафта (камни, деревья). Поэтому создание и изменение функции нового места было по тем временам необычным. Например, старейшина Палаты народных верований Ахто Каазик считал в то время, что никакая это не священная роща, однако этот вопрос Туле Леэ уладила, разъяснив, что где-то есть начало священных рощ, и если существует традиция собираться вместе и знание, в чем нуждаются люди, то есть и сила (Thule Lee 2013). На ее ритуальной территории установлены фогуры различного происхождения и копии мировых священных мест ступа, миниатюрный мегалит-Стоунхендж, соломенный идол, (солнечное) колесо на вершине высокого столба и др. Внешнее оформление дома также включает в себя природные и религиозные символические элементы, являющиеся примером неоспиритуалистической архитектуры, своеобразной пространственной идеологии, определенной личным выбором.

Информация о времени проведения ритуалов распространяется в Интернете (на сайте, форумах), СМИ (в первую очередь в предназначенных для местных жителей заметках и интервью в местной газете и центральных СМИ), важная роль отводится распространению информации в социальных и неформальных сетях, а также через тех, кто участвовал в мероприятиях ранее. Проведение обрядов в честь дней равноденствия и солнцестояния освещено в СМИ, к участию в них приглашаются как приезжие (в основном горожане), так и местные жители. Количество участниц варьируется от 3 до 23.

Поскольку люди прибывают из разных мест и всегда есть новички, на сайте можно предварительно ознакомиться с требованиями к жертвенным дарам и предметам, которые надо взять с собой: свои глиняная миска, чашка, ложка, что-то съестное. Строго предписано облачение, заметно отличающееся от повседневного:

[---] национальные или длинные обрядовые юбки, на голову платок, за пояс - нож. Зимой приходить в теплой одежде. Не надевать городские куртки! Лучше шубы, пальто - то, что сочетается с национальной одеждой. Надеть и взять с собой свои обрядовые предметы, рубахи, талисманы! С собой иметь разные жертвенные ленты: для Таары - белую, для матери огня - красную, для матери ветра - синюю, для матери воды - голубую, для 
матери леса - зеленую, для матери хлеба - золотую, для матери земли - коричневую, для матери скота - оранжевую с зеленым и белым, для праматерей - черно-белую, для матери очага оранжевую с черным и серым, для матушки-ели на священном месте - лиловую. (Mölder 2010; Thule Lee 2011)

В современной традиции различные цвета зачастую отождествляются с тем или иным духом, что обусловлено общепринятой цветовой символикой или восточной практикой. Цвета современных жертвенных лент поражают своим разнообразием в сравнении с использовавшимися в старину тремя-четырьмя цветами. Обратите внимание на ношение платка (признак женщины) и нож за поясом - признак хозяйки, независимой женщины.

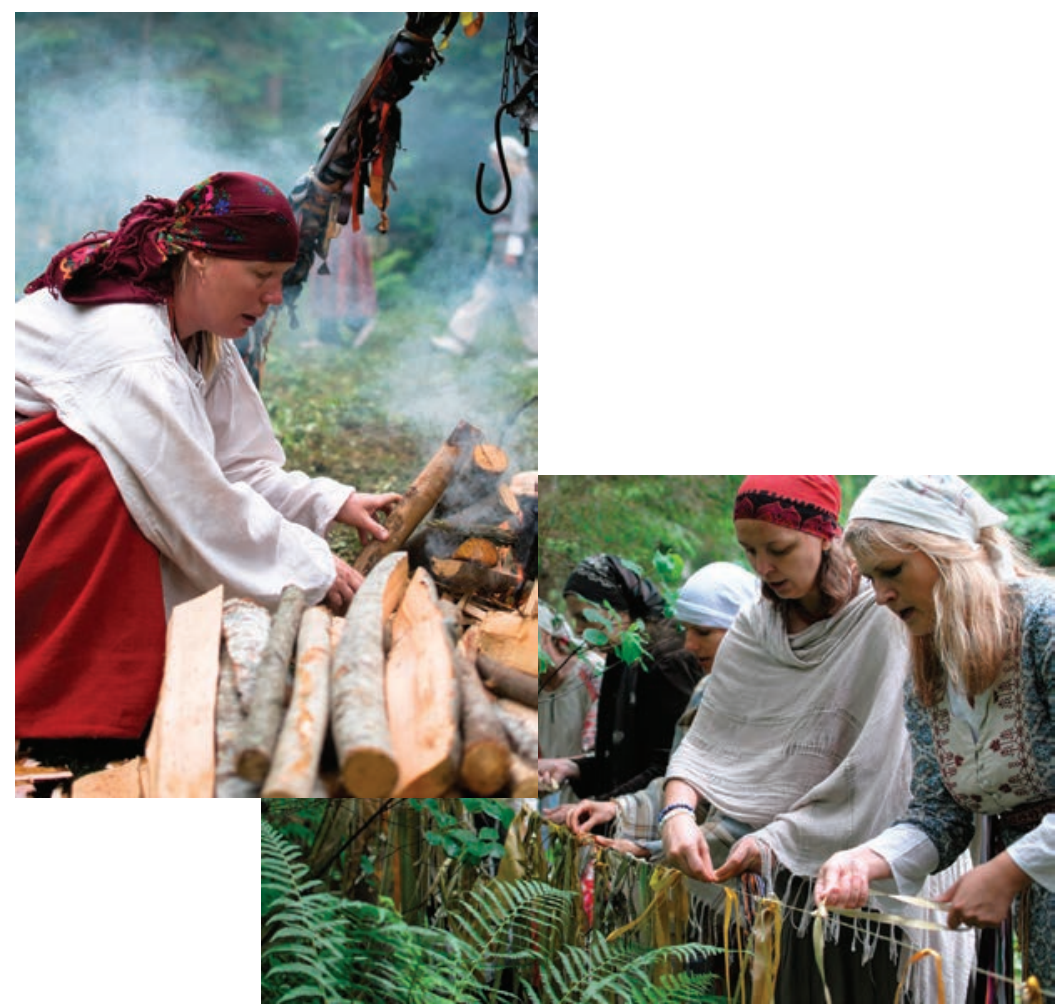

Фото 1 и 2. Обряд женской силы в Леэсоя. Фотографии из частного архива Туле Леэ 2013. 
Структура ритуала определена относительно четко: участницы должны прибыть на место к 9.30 утра в субботу или воскресенье после дня равноденствия/солнцестояния. Ритуал и приготовление каши начинаются, когда солнце стоит высоко - принимается во внимание жизненный стандарт прибывших издалека городских жителей.

Прибывшие накануне должны иметь с собой спальное снаряжение. Предшествующий ритуалу Мерле письменный инструктаж охватывает все ритуальные элементы и основные правила, которые повторяются непосредственно перед началом ритуала: «Я еще раз рассказываю об обряде перед тем, как идти в священную рощу, где все также предварительно представятся друг другу» (Mölder 2010; Thule Lee 2011).

Затем следует приглашение матерей природы на кашу и жертвоприношение. Имена духов-хранителей изменены с матерей на мам (эст. етmе) - «приглашаем мам мира». Эта уменьшительная форма слова «мать» (эст. ета) распространилась в языке в 1970-х годах, сменив альтернативные обращения. Возможно, она используется для создания чувства единения представителей молодого поколения с людьми среднего возраста, а также со сверхъестественными существами. Употребляется и слово mamma - популярное в городской традиции начала прошлого века обращение к матери, которое позднее стало использоваться чаще в значении «бабушка».

По очереди начинают приглашать всех "мам мира» готовить кашу, принося им различные жертвы (яйца, домашний хлеб, воду), задабривая их. И потом они станут первыми, кто получит первый половник священной каши (Mölder 2010).

Мы идем по кругу против солнца. Руководствуясь как книгой Сасся ${ }^{5}$, так и своей интуицией, я изменила также цвета жертвенных лент, и мы поем только песни, прославляющие женскую силу, но не поем, что женщины бедные-несчастные. Я считаю, что важно настроиться на позитив (Thule Lee 2013).

Женские ритуалы проводятся четыре раза в год, что сближает их с мировыми колдовскими и неоязыческими практиками. Например, в последние годы день осеннего равноденствия называют Мабон (Thule Lee 2016, ср. напр. Witch Ritual 2017; White Witch Parlour 2017).

Туле Леэ творчески комбинирует различные знания и ритуалы, не боится экспериментов и ориентирована на саморазвитие: 
«Я непрерывно занимаюсь самосовершенствованием, исследуя тайны человеческой психики. Мне нравится создавать новые психотехники и практические упражнения. Я ищу способы полностью расслабиться, получить доступ к своему подсознанию и скрытым пока способностям» (Mölder 2010, Овальная студия, личный архив).

Наряду с эстонскими традициями, она придает важность практикам восточного происхождения (йога, тантра) и әкспериментирует с ними. Последние предпочтения поддерживает спутник жизни Мерле, являющийся известным инструктором по йоге и помогающий исцелять людей. Таким образом, они представляют собой тандем, созданный посредством духовности и совместной деятельности. Родившийся в 1966 году партнер рассказывает о себе:

Восточная обращенность внутрь себя для меня ближе, чем западное стремление влиять на внешний мир. Я пытаюсь разрабатывать сильнодействующие психотехнологии и наносить на карту ландшафт человеческого подсознания. [---] На мое мировоззрение оказали большое влияние классические естественные науки и квантовая физика, а также представление о так называемом фундаментальном фоне («кипящий вакуум»), кашмирский тантризм, каула-шактизм, дзен-буддизм, попытки объединить восточный и западный образ мышления (великая цепь бытия К. Уилбера), глубинная экология (Mölder 2010, Овальная студия).

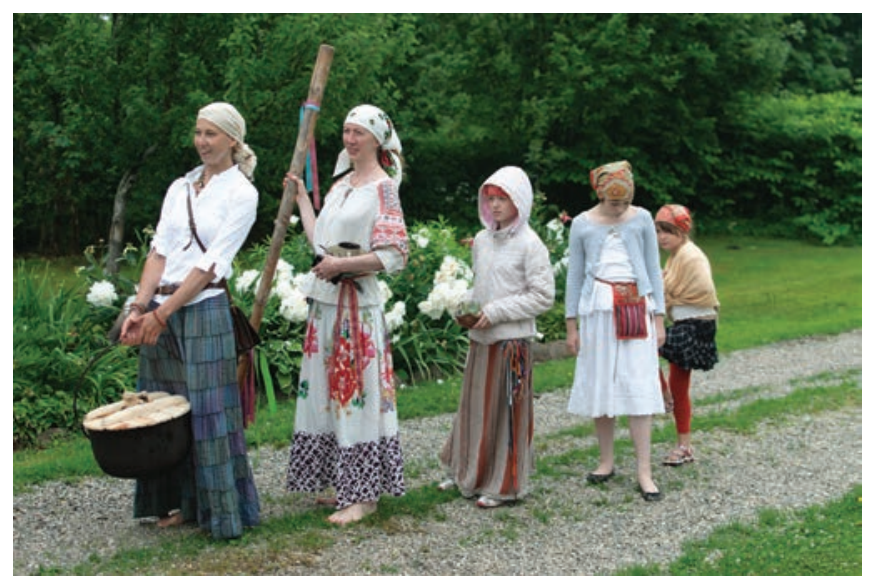

Фото 3. Обряд женской силы в Леэсоя. Фотографии из частного архива Туле Леэ 2013. 
На сегодняшний день ее обряды посвящены тантризму и обретению сексуальной гармонии, чему способствует популярность йоги и тантризма в обществе.

\section{Посредница между культурами, возрождающая ритуалы}

Эне Лукка-Егикян (р. 1954) обладает, по всей видимости, большим опытом включения базирующихся на фольклоре ритуалов в современный культурный контекст (о воссоздании задействующих заговоры ритуалов см. «Loitsust riituseni», Kõiva 1995). Трудовая жизнь получившего высшее образование работника культуры началась в 1977 году в Вильянди, в техникуме для библиотекарей и работников культуры, и продлилась до 2010 года. Переломным стал 1991 год, когда образовательное учреждение получило статус высшего прикладного училища и там появилась возможность для полноценной разработки учебных программ в области традиционной культуры и для научно-методического руководства. Параллельно она проводила по всей Эстонии курсы по фольклористике, краеведению, генеалогии и т.п. для работников культуры. Популярные серии лекций проходили в столице, однако вскоре стали проводиться по всей стране. Курсы охватывали широкий круг тем: сказительство и формы религии, календарная традиция, народная музыка, традиционные праздники, народная этика, основанный на устных договоренностях юридический кодекс сельской общины и др. Эне Лукка-Егикян выступала в различных фольклорных коллективах и, подобно другим фолк-музыкантам, начинавшим в 1970-х годах, собирала музыкальный фрольклор, вдохновлялась живым исполнением, однако пользуется и собственными познаниями в области традиционной культуры, поскольку часть ее песенного репертуара происходит из дома.

Одной из вех на пути ее развития стало создание теле- и радиопередач, посвященных важным датам народного календаря. Формат предполагает знание основных элементов и структуры обрядности, умение визуализировать их. Естественным продолжением ее начинаний стало в 1996 году проведение ритуалов. Сначала она записала ритуал в честь Благовещения, считавшегося праздником молодых женщин, затем последовали, напр., 
юношеский ритуал в честь Юрьева дня, а также совместные ритуалы в честь Дня Кадри, Мартова дня, Дня всех усопших верных и Троицы. Каждому празднику она присвоила условную общую тему, например День всех усопших верных предназначен для воспоминаний о прошлом и поминовения усопших, важно также рассказывать другим о своих близких. Эти значимые даты характеризует оркестровка, которая задействует всех членов семьи (следуя традиционной обрядности, на Троицу приносят из леса березки, заготавливают вместе веники для бани и др.). Современным нововведением является, например, приглашение местного ботаника, рассказывающего участникам о произрастающих в окрестностях лекарственных растениях, которые потом собирают. Иногда в ходе ритуалов посещают различные природные места, например болота, что производит на урбанизированных участников незабываемое впечатление.

Своей задачей она ставит популяризацию старинных праздников среди молодежи, подразумевающую хотя бы частичное сохранение их первоначального значения. Первоочередной задачей она считает изменение обрядов таким образом, чтобы их можно было использовать в современном обществе и семейной жизни (Lukka-Jegikjan 2006b: 151). На ее взгляд, ритуалы важны для напоминания о жизненно важных вопросах и обретения внутренней гармонии, принимая во внимание локальные особенности обрядов. Цель празднующих - вдохнуть в ритуал жизнь и найти в празднике себя. По ее словам, важную роль играет так называемый «институт странствующего организатора ритуалов» она проводит их в самых разных уголках Эстонии.

Фото 4. Благовещение в Париже. Фото Марты Мармор, 2013.

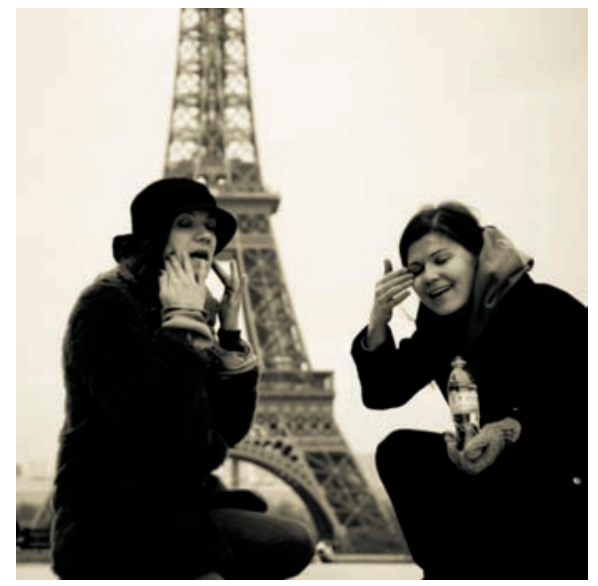


Рассмотрим подробнее празднование Благовещения. Непосредственно перед восходом солнца омывают глаза ключевой водой и собираются до шести утра, приветствуя солнце хоровой песней (песни о сотворении мира, солнечные заговоры и др.). Ритуал проводит Э. Лукка-Егикян, благодаря знанию традиционной обрядности и структуры ритуалов. Она раздает участникам задания и обучает их, является запевалой, определяет начальный и конечный пункты обрядовых элементов. Используется ролевое наименование "хозяйка» (и "хозяин»). Если кто-то проводит ритуал у себя дома, то роль проводника и хозяйки достается ей. На утреннем приветствии солнца и в дневной/вечерней части праздника рады и детям.

В ходе длящегося около часа ритуала хором поют эпические песни, играют в песенные игры, чтобы согреться. Эту часть ритуала завершает небольшое жертвоприношение в форме повязывания на дерево ленты, при этом можно загадать чтонибудь для себя и своих близких.

Затем следует совместное приготовление праздничных блюд, напр. на Благовещение это блины и традиционный красный напиток. Еду и питье можно приготовить и раньше и взять с собой из дома к общему столу, то же касается и необходимых для ритуала предметов - информация обо всем отправляется заранее.

Эне Лукка-Егикян делает частью ритуалов воспоминания и память: называют имена прабабушек, сообщают о происхождении своего имени, поют так называемые женские песни и рассказывают женские истории, ведется запись обрядов. Для многих участниц разговоры о близких и самовыражение посредством историй являются новым опытом. Поскольку зачастую в ритуале участвуют люди разного возраста, обладающие различным опытом, возникает чувство посвященности, преодолевающее границы между поколениями. Так подводит итог одна из участниц:

Отрадно, что пришли и некоторые бабушки, и мои дочери были не единственными представительницами своего поколения. Так мы смогли пообщаться в кругу трех поколений, несмотря на то, что самые юные были скорее в роли слушательниц, однако таким образом и они получают опыт (Lukka-Jegikjan 2006: 154).

При возможности накануне вечером ходят вместе в баню или проводят после ритуала праздник с гаданиями, песнями, играми и обыгрыванием народных обычаев (являющееся частью 
свадебного обряда надевание чепца, обычаи, связанные с детьми, необходимые женщинам и матерям практические знания). Поскольку в ритуале принимают участие только женщины, подчеркивается, как важно в знак почтения к ритуалу рассказать о нем домашним и друзьям. При посредничестве участников ритуалы распространяются по различным областям Эстонии, где у них появляются свои местные проводники, продолжающие отмечать праздники в родном краю.

К ритуальному облачению предъявляются минимальные требования, подчеркивающие, тем не менее, самобытность происходящего - белый платок на голову, замужние женщины должны повязать передник - оба элемента являются частью дресс-кода XIX века. При возможности рекомендуется надевать национальную одежду, которая обычно имеется у тех, кто поет в хоре и занимается народными танцами, однако носят ее только во время выступлений. В наши дни необычным для девочек является и ношение юбки. Таким образом, элементы ритуала являются временным дополнением или заменой современной модной одежды, так называемой праздничной одеждой, подчеркивающей необычность, духовность или альтернативность происходящего.

В ритуалах принимают участие представители различных социальных групп: учащиеся, студенты, слушатели курсов традиционной культуры Эстонского национального фольклорного совета, предводители фольклорного движения, члены объединений сельских женщин, а также простые местные жители - возраст женщин простирается в среднем от 18 до 60 лет, преимущественно это активные женщины среднего возраста. Например, в 2013 году к празднованию Благовещения с приветствием солнца, совместной трапезой, песенно-сказительной частью присоединились девочки из Раннуской школы. Это был впечатляющий опыт благодаря как темам для обсуждения, так и возможности поиграть в давно забытые песенные игры.

Обычно женские ритуалы проводятся совместно с местными жителями в парке или на берегу местного водоема, где открывается хороший вид на восход солнца, или за пределами поселения. Если в окрестностях имеются особенные места (памятники археологии, истории или природы, качели и места сбора), то для проведения ритуала подходят они. Проходящая в помещении часть ритуала проводится в культурном центре, на туристическом хуторе или в местной гостинице. 


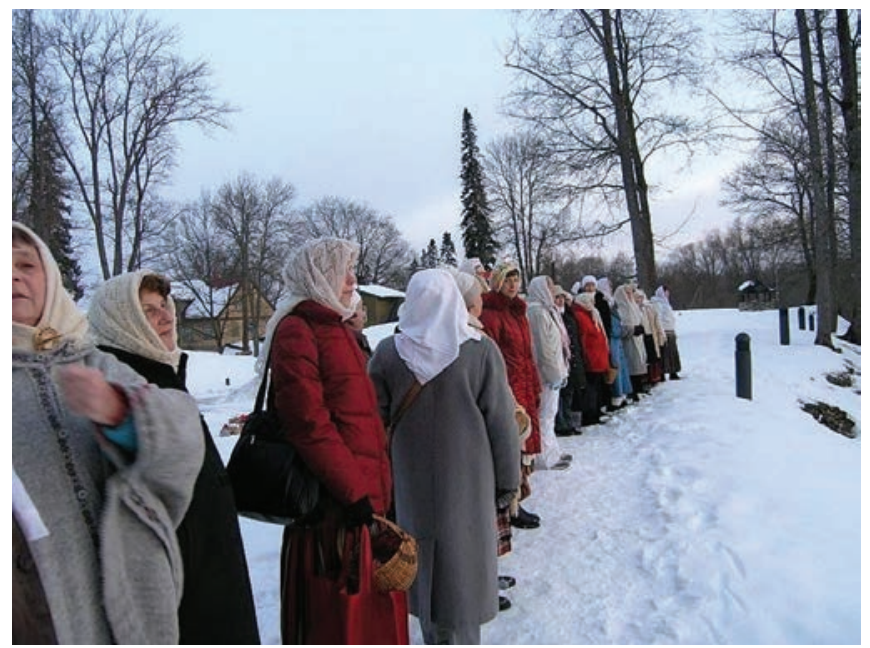

Фото 5. Благовещенский обряд в Пайде. В ожидании солнца. Фото из частного архива Эне Лукка-Егикян, 2010.

\section{Современные особенности новых ритуалов}

Известные исследователи неорелигий Пол Хилас, Линда Вудхед и др. (Heelas и др. 2005: 3, 60 и далее) указывают, что, несмотря на многовековую историю религий, роль женщин как религиозных лидеров в ней является ничтожной, однако неоязычество и объединения нью-эйдж позволили женщинам выступать в роли творца и лидера. Языческое движение США считается основной возможностью женщин создать духовную альтернативу, они привнесли с собой новые объединения, социальные сети и действия (cp. Jörgensen \& Russell 1999: 326 и далее). В какой-то степени это касается и рассматриваемых случаев: нео-спиритуалистические женские ритуалы развивались наравне с совместными ритуалами и выросли из них, вместе с тем преподаватель культурных практик начинала с женских ритуалов и перешла к совместным. Таким образом, создаются микросоциальные коммуникативные акты, предполагающие наличие культурной компетентности. Речь идет не просто о стандартной 
устойчивой религиозной группе или группе по интересам, а о группах с изменчивым составом участников, объединяемых общим интересом и признанием лидера. Значительная модернизация ритуалов, иными словами, изменившаяся совокупность социально-экономических и культурно-демографических фракторов, повлекла за собой изменения гендерных ролей. Это является частью более широкого дискурса, напр. американские языческие лидеры проводят мужские ритуалы, знаменующие переход из одной возрастной группы в другую (см. Riley 2011; Barner-Barry 2005: 35 и далее). Также стало актуальным ценить свою инаковость, роль жены и матери, которые существовали в обществе декларативно, по сути, на заднем плане. Оба организатора ритуалов подчеркивают значение семьи, связь с опытом предыдущих поколений, или так называемой женской силой. В их ритуальных практиках принимают участие дети, а мужские ритуалы проводят члены семьи.

Важная роль отводится контактам с представителями неоспиритуализма, напр. дружба Эне Лукка-Егикян с латышами Аидой Ранцане и Андрисом Капустсом, которые руководят празднованием Благовещения и народных языческих праздников в Риге, Туле Леэ ссылается на опыт участия в ритуалах Эло Лийв и знание учения Вигала Сасся.

Знания о верованиях и ритуалах заимствуются из местной традиции, напр. американское неоязычество использует элементы индейских, афроамериканских и др. синкретических религий, таких как вуду и сантерия (Jörgensen \& Russell 1999: 326 и далее), в Эстонии особую роль в формировании и наполнении смыслом ритуалов играют народные песни и заговоры (cp. Bordieur 1994: 107), они используются для общения с сакральным и божествами. Использование народных песен схоже с обрядностью ближайших соседей - прибалтов, которую Майкл Стрмиска (2005) характеризует так: «В неоязыческом движении Латвии и Литвы важная роль отводится народной музыке, несущей ряд различных функций. Она является ритуальным действием, элементом общинной идентичности и священным текстом - это музыкальное святое писание, если хотите. Однако в числе лидеров этого движения много ученых, собирателей и исполнителей такой музыки». В Эстонии ситуация является несколько иной, поскольку лидеры движения за воссоздание народных песен редко занимаются возрождением әстонской 
традиционной религии и календарной традиции. Одним из исключений является Микк Сарв (1988), который, преподавая в школе в Вильянди, указывал путь к архаическим слоям календарной традиции, учил сливаться в одно целое с песнями и создавал предания, интерпретируя вымышленные миры.

Ритуал Туле Леэ включает в себя жертвоприношение духам природы (в контексте неоспиритуализма - стихиям, элементам), обращение к ним с импровизированными авторскими заговорами и просьбами. Лукка-Егикян связывает жертвоприношение с загадыванием желаний, проводится параллель с реальными представительницами предков по женской линии. Структура ритуала неизменна (cp. Whitehouse \& McCauley 2005). Самобытность мероприятия подчеркивают кодекс одежды, питания и поведения. Здесь мы доходим до важных различий: Эне Лукка-Егикян обладает обширными познаниями в области традиционных песен и обрядов, т.е. ее ритуалы остаются в более строгих рамках. Туле Леэ отводит большое значение восточным учениям и практикам, авторским наработкам, она очень творческий человек, поддерживающий жизнь на периферии, на своей земле, которую она украшает в соответствии со своим мировоззрением.

В рассмотренных ритуалах свою роль играет знание православной обрядности и песенной традиции: при реконструкции использованы черты отмечавшихся на православных окраинах женских и мужских праздников, послуживших основой для создания ритуалов. Женский ритуал основан на совместной деятельности, при которой придается значение участию и личному опыту (cp. Norris \& Inglehardt 2004: 34), а также эмоциям. Таким образом, речь идет не только о реконструкции и возрождении старинных обычаев, но и о личном выборе и самоутверждении в современном обществе, о целиком и полностью современном независимом дискурсе. Организаторы ритуалов являются харизматичными личностями, поставившими перед собой цель посредством участия в ритуалах совершенствовать себя и свою идентичность, они позволяют получить опыт приобщения, кардинально отличающийся от городской рутины. Ритуалы характеризуют послания и опыт, влияющие на жизненный уклад, их цель состоит в том, чтобы жить в гармонии с близкими и собой, отсутствует агрессивный и враждебный посыл. Губерт Херманс (2001) приходит к выводу, что «все возрастные группы или культуры используют истории и нарративы (миф, фольклор, 
сказка, легенда, эпические песни, опера, фильм, биография, роман, телепередача, авторская шутка и мн. др.), чтобы придать смысл своей среде и своей жизни». Помимо вышеупомянутого, ритуалы помогают обрести внутренний баланс и снизить неуверенность, которая, согласно Хермансу и Димаджо (2005), «мотивирует индивидов и группы находить локальные ниши в процессе конструирования идентичности».

Теоретические концепции на протяжении долгого времени рассматривали город как осмысление комплексного социального пространства (напр., Lefebvre 1991; Soja 1996). В данном случае изменяется значение пространства, необходимое для ритуала сакральное пространство создается в городе: в парке, в роще на городской окраине, недалеко от дома, у воды -ценностью место наделяет проводимый там ритуал. Иногда дискурс священного места включает в себя также обладающие различным смыслом памятники истории и культуры разных эпох, как археологические, так и важные исторические. Совсем другие возможности для симбиоза предоставляет созданное лидером (и последователями) этнической религии на своей земле, в хуторской среде специальное место для проведения ритуалов. Последнее можно считать расширением понятий «святость» и «священное место». В процессе расширения важную роль играет свойственный неорелигиозным движениям экологический образ мышления (см. van Gulik 2010), приверженность которому выражают и рассматриваемые в данной статье ритуальные лидеры. Так или иначе, рассмотренные неоспиритуалистические, а также возрождающие более торжественную часть праздничной культуры ритуалы соответствуют описанию С. Тамбия, вместе с тем хотелось бы возразить У. Саксу, что в такой фрорме они являются эфрфективными и необходимыми для личностного развития и организации идентичности, а также представляют собой мероприятия, придающие важность ближайшей окружающей среде.

\section{Выражение благодарности}

Работа осуществлена при поддержке Министерства образования и науки Эстонии (институциональный исследовательский грант IUT 22-5, ETF 8137) и Фонда регионального развития ЕС (Центр компетенции по Эстонским исследованиям CEES - TK 145). 
Ранняя версия статьи: Kõiva, Mare 2011. Women's Holidays and Porridge Rites. The Inner And the Outer. The Ritual Year 6. The Yearbook of the SIEF Working Group on the Ritual Year. Tartu: ELM Scholarly Press, cc. 83-106.

\section{Примечания}

1 О совместных ритуалах Паневритмии см. Toncheva 2017, а о ритуалах, связанных с днями солнцестояния и равноденствия - Kõiva 2017.

${ }^{2}$ Пеко - сетуский бог плодородия, небольшой деревянный идол, который передавался по наследству и хранился в хлебном амбаре.

3 Одним из наименований Благовещения в Южной Эстонии было День каши (эст. pudrupäev).

4 Старинное песенное богатство - написанные в размере «Калевалы» или в схожем ритме с использованием аллитерации песни, традиция исполнения которых угасла преимущественно еще в XIX веке.

5 Труды Вигала Сасся широко использовались при составлении ритуалов.

\section{Литература}

Barner-Barry, Carol 2005. Contemporary Paganism: Minority Religions in a Majoritarian America. New York: Palgrave Macmillan.

Bourdieu, Pierre 1994. Language and Symbolic Power, 3. издание. Harvard: Harvard University Press.

Gergen, Kenneth J. 1999. Social Construction and the Transformation of Identity Politics. Draft copy. Newman, Fred; Holzman, Lois (ред.). End of Knowing: A New Developmental Way of Learning. New York: Routledge.

Hagu, Paul 1975. Setu viljakusjumal Peko. [Сетуский бог плодородия Пеко.] Keel ja Kirjandus 3, cc. 166-172.

Hanegraaff, Wouter J. 1996. New Age Religion and Western Culture: Esotericism in the Mirror of Secular Thought. Studies in the History of Religions 72. Leiden: E. J. Brill.

Heelas, Paul \& Woodhead, Linda \& Seel, Benjamin \& Szerszynski, Bronislaw \& Tusting, Karin 2005. The Spiritual Revolution: Why Religion Is Giving Way to Spirituality. Oxford: Blackwell Publishing. 
Hermans, Hubert J. M. 2001. The Dialogical Self: Toward a Theory of Personal and Cultural Positioning. Culture \& Psychology 7, cc. 243-281 (DOI:10.1177/1354067X0173001).

Hermans, Hubert J. M. \& Dimaggio, Giancarlo 2005. Self, Identity, and Globalization in Times of Uncertainty: A Dialogical Analysis. Terzo Centro di Psicoterapia Cognitiva (DOI: 10.1037/1089-2680.11.1.31).

Hiiemäe, Mall 1981-1999. Eesti rahvakalender 2-8. [Эстонский народный календарь.] Tallinn: Eesti Raamat.

Jorgensen, Danny L. \& Russell, Scott E. 1999. American Neopaganism: The Participants' Social Identities. Journal for the Scientific Study of Religion 38 (3), cc. 325-338.

Krumina-Konkova, Solveiga 2004. New Religious Minorities in the Baltic States. Lucas, Phillip Charles; Robbins, Thomas (ред.). New Religious Movements in the Twenty-first Century: Legal, Political, and Social Challenges in Global Perspective. New York \& London: Routledge.

Kõiva, Mare 1995. From Incatations To Rites. Kõiva, Mare \& Vassiljeva, Kai (ред.). Folk Belief Today. Tartu: Eesti Keele Instituut, cc. 215-236.

Kõiva, Mare 2013. Calendar feasts: Politics of adoption and reinstatement. Laineste, Liisi \& Brzozowska, Dorota \& Chłopicki, Władisław (ред.). Estonia and Poland: Creativity and change in cultural communication. Tartu: EKM Teaduskirjastus, cc. 187-210.

Kõiva, Mare 2017. Constructing Contemporary Periodical and Occasional Rituals. Ekaterina Anastasova \& Mare Kõiva (ред.). Balkan and Balticum. Current Studies in the Postsocialist Space. Sator 18. Tartu: ELM Scholarly Press, cc. 199-220.

Kõiva, Mare 2018. Constructing New Spirituality in Modernity - the Case of the White Brotherhood in Bulgaria. Ekaterina Anastasova \& Mare Kõiva (ред.). Balkan and Balticum. Current Studies in the Postsocialist Space. Sator 18. Tartu: ELM Scholarly Press, cc. 183-199.

Kõiva, Mare \& Särg, Taive \& Vesik, Liisa 2004. BERTA: Eesti rahvakalendri tähtpäevade andmebaas. [Эстонский народный календарь, база данных.] http://www.folklore.ee/Berta/ (дата обращения 11.04.2013).

Kõiva, Mare \& Vesik, Paul 1990. Vigala Sassi pööripäevaloits. [Заговор солнцестояния Вигала Сасся.] Tartu: Eesti Folkloristika Keskus, Tartu Ülikooli õppefilmide stuudio. 
Lefebvre, Henri 1991. The Production of Space. Oxford: Whiley-Blackwell.

Liiv, Elo 2009. Aleksander Heintalu ja Elo Liivi kodulehekülg. [Домашняя страница Александера Хейнталу и Эло Лийв.] http://eloliiv. wordpress.com = http:// eloliiv.wordpress.com/2009/05/20/moonikasiimets-oma-maitse/ - 11.04.2013.

Linnard, Tiina 2002. Elo Liiv - Vigala Sassi viljakas õpilane. [Эло Лийв - продуктивная ученица Вигала Сасся.] Põhjarannik, 23.11. http://arhiiv.pohjarannik.ee/ article.php?sid=2777 (дата обращения 11.04.2013).

Loorits, Oskar 1940. Das sog. Weiberfest bei den Russen und Setukesen in Estland. Oppetatud Eesti Seltsi Aastaraamat 1938/2. Tartu 1940, cc. 259-330.

Lukka-Jegikjan, Ene 2006a. XXI sajandi eesti naine - järjepidev kultuurikandja. [Эстонская женщина XXI века - последовательный носитель культуры.] 2. выпуск. Tallinn: Rahvakultuuri Arendus- ja Koolituskeskus.

Lukka-Jegikjan, Ene 2006b. Tähtpäevade ja pühade tähistamisest Viljandi Kultuuriakadeemias. [О праздновании знаменательных дат и праздников в Вильяндиской академии культуры.] Mäetagused 32, cc. 151-164. http://folklore.ee/tagused/nr32/lukka.pdf (дата обращения 11.04.2013).

Lätt, Selma 1970. Eesti rahvakalender 1. [Эстонский народный календарь.] Tallinn: Eesti Raamat.

Maajumalate park [Парк богов земли] 2009. http://www.tervisesport.ee/ maa<jumalate-park (дата обращения 11.01.2018).

Mölder, Merle 2010. Iseendasse [В себя] (http://www.iseendasse.planet. ee/index. php?option $=$ com_content $\&$ view $=$ article\&id $=22 \&$ Item $\mathrm{id}=28$ = Workshop: tantra pühendumise praktika. Ovaalstuudio. Loovarengukeskkond (http:// ovaal.ee/sundmused/workshopi-saritantra/ - 11.04.2013).

Norris, Pippa \& Inglehardt, Ronald 2004. Sacred and Secular: Religion and Politics Worldwide. Cambridge, United Kingdom: Cambridge University Press.

Pulk, Kadri 2008. Persoon: Merle Tombak julgeb talitada oma sisetunde ja südamehääle suuniste järgi. [Персона: Мерле Томбак не боится поступать, руководствуясь интуицией и голосом своего сердца.] Valgamaalane, 07.06. http://wwx.valgamaalane.ee/070608/ esileht/25014157_print.php (дата обращения 03.07.2013). 
Riley, Terry Michael 2011. Brothers of the Sun: Pagan Men Mysteries. Memphis: Heka House Publishing.

Ringvee, Ringo 2011. Riik ja religioon nõukogudejärgses Eestis 1991-2008. [Государство и религия в постсоветской Эстонии 1991-2008.] Dissertationes Theologiae Universtitatis Tartuensis 23. Tartu: Tartu Ülikooli Kirjastus. http://dspace.utlib.ee/dspace/handle/10062/17525 (дата обращения 10.01.2018).

Salong, Heli 2010. Elo Liiv: võtame kevadet vastu kui kauaoodatud külalist. [Эло Лийв: встретим весну, как долгожданного гостя.] Meie maa, 3.04. http://www.meiemaa.ee/index. php?content=artiklid\&sub= $1 \&$ artid=35444 (дата обращения 10.01.2018).

Sarv, Mikk 1988. Rahvakalendri tähtpäevad: soovitusi temaatiliste klubiürituste korraldamiseks. [Знаменательные даты народного календаря: рекомендации по организации тематических клубных мероприятий.] Tallinn: Eesti Raamat.

Sax, William S. \& Quack, Johannes \& Weinhold, Jan 2010. The Problem of Ritual Efficacy. New York: Oxford University Press.

Siimets, Ülo 2001. Vigala Sassil külas. [В гостях у Вигала Сасся.] Lee 7, cc. $36-43$.

Soja, Edward W 1996. Thirdspace Journeys to Los Angeles and Other Real-and-Imagined Places. Oxford: Basil Blackwell.

Sökefeld, Martin 1999. Debating Self, Identity, and Culture in Anthropology. Current Anthropology 40 (4), cc. 417-448 (http:// dx.doi. org/10.1086/200042).

Strmiska, Michael 2005. The Music of the Past in Modern Baltic Paganism. Nova Religio: The Journal of Alternative and Emergent Religions 8 (3), cc. 39-58 (http://dx.doi.org/10.1525/nr.2005.8.3.39).

Tambiah, Stanley Jeyaraja 1979. A performative approach to ritual. Proceedings of the British Academy 45, cc. 113-169.

Tampere, Herbert 1960. Eesti rahvalaule viisidega II. [Эстонские народные песни с мотивами.] Tallinn: Eesti Riiklik Kirjastus.

Thule Lee 2011. Vanade kommete hingestamine. Sügispööripäeva rituaal Leesoja hiies. [Оживляя древние традиции. Ритуал осеннего равноденствия в священной роще в Леэсоя.] Vikerkaaresild, 03.07.2013 (http://www. vikerkaaresild.org/et/node/9513). 


\section{МАРе КЫЙвА}

Van Gulik, Léon 2010. On the Pagan Parallax: A Sociocultural Exploration of the Tension between Eclecticism and Traditionalism as Observed among Dutch Wiccans. Pomegranate. The International Journal of Pagan Studies 12 (1), cc. 49-70 (DOI: 10.1558/pome.v12i1.49).

Viks, Tiina 2009. Mütoloogilised ja muinasjutulised puukujud - Elva Nokia. [Мифологические и сказочные деревянные фигуры - эльваская Нокиа.] Рукопись бакалаврской работы. Tartu: Tartu Ülikool.

Whitehouse, Harvey \& McCauley, Robert (ред.) 2005. Mind and religion: Psychological and cognitive foundations of religiosity. Oxford, UK: Altamira Press.

York, Michael 2001. New Age Commodification and Appropriation of Spirituality. Journal of Contemporary Religion 16 (3), cc. 361-372 (http://dx.doi.org/10.1080/13537900120077177).

\section{Summary}

\section{Distinguishing Features of Contemporary Female Rituals}

\section{Mare Kõiva}

Keywords: calendar feasts, maausk (Earth belief), Estonian new religious movement, ethnic religous movements, neopaganism, reinvention, porridge rites, structure of rituals, women's rituals

The author aims to describe the contemporary trend of establishing womenonly rituals, in particular the porridge rites, which are some of the new contemporary (ethnic) religious and cultural phenomena in Estonia. All these celebrations have different roots in and impressions on society, they are a syncretic mixture of Estonian calendar rituals with additions from the Finnic-Ugric folklore, New Age philosophy and practice, as well as the maausk (Earth belief) movement. Two micro-social scenarios of women-only rituals (reinvented with the help and on the basis of folklore, and printed scholarly books), their structure and setting are described.

Time and space requirements of the rites, clothing etiquette and symbolics as well as the structure of constructed celebrations are influenced by the demands of the contemporary society. Personal experience, socialisation with rite participants and so-called women's power are important for both the leaders and participants of the rites. New forms of rituals are closely connected with construction of the self and identity, as well as personal creativity. 


\section{МИССИЯ ВЫПОЛНИМА Перспективы изучения фольклора}

http://www.folklore.ee/rl/pubte/ee/sator/sator19/

ISSN 1736-0323

ISBN 978-9949-586-60-8

DOI: $10.7592 /$ Sator.2018.19

Тарту 2018

Редакторы-составители выпуска:

Маре Кыйва \& Татьяна Володина

Редактор серии: Маре Кыйва

Фото: Яак Кикас, 2018 «Осень в Тарту»

Оформление обложки: Лииса Весик

Верстка \& HTML: Диана Кахре

Печатное издание: МИССИЯ ВЫПОЛНИМА:

Перспективы изучения фольклора. SATOR 19. Тарту 2018

Публикация книги осуществлена совместно Эстонским литературным музеем и Центром исследований белорусской культуры, языка и лит ерат уры Националь ной акад емии наук Б еларус и, п ри поддержке Министерства образования и науки Эстонии (IUT 22-5), Фонда регионального развития ЕС (ТK 145, Центр компетенции по Эстонским исследованиям); при поддержке проекта, финансируемого Министерством иностранных дел Эстонии из бюджета по сотрудничеству и развитию, Эстонской Академией Наук и Национальной академии наук Беларуси.

Оформление электронного издания осуществлено при поддержке проекта ЕККМ14-344 “Расширение областей применения и представление эстонского языка, культуры и фольклора в электронных информационных средствах".

() Эстонский литературный музей

(c) Авторы

(с) Яак Кикас 